\title{
Production of environmentally friendly aerated concrete with required construction and operational properties
}

\author{
Evgeniya Tkach $^{1, *}$, Vladimir Solovyov ${ }^{2}$, and Semen Tkach $^{3}$ \\ ${ }^{1}$ National Research Moscow State University of Civil Engineering, 129337 Moscow, Russia \\ ${ }^{2}$ Euroasia MS LLP, 050060 Almaty, Republic of Kazakhstan \\ ${ }^{3}$ Financial University under the Government of the Russian Federation, 125993 Moscow, Russia
}

\begin{abstract}
The purpose of these studies is to justify the feasibility of recycling different types of industrial waste instead of conventional expensive raw materials in production of environmentally friendly aerated concrete with required construction and operational properties. The impact of wastes from various industries on the environmental condition of affected areas, as well as the results of their environmental assessment were analyzed to determine whether these wastes could be used in production of high-performance building materials. The assessment of industrial wastes in aerated concrete production suggests that industrial wastes of hazard class IV can be recycled to produce aerated concrete. An environmentally friendly method for large-scale waste recycling, including a two-step environmentally sustainable mechanism, was developed. The basic quality indicators of the modified aerated concrete proved that the environmental safety could be enhanced by strengthening the structure, increasing its uniformity and improving thermal insulation properties. The modified non-autoclaved aerated concrete products with improved physical and operational properties were developed. They have the following properties: density - D700; class of concrete $-\mathrm{B} 3.5$; thermal transmittance coefficient $-0.143 \mathrm{~W} /\left(\mathrm{m} \cdot{ }^{\circ} \mathrm{C}\right)$; frost resistance $-\mathrm{F} 75$.
\end{abstract}

\section{Introduction}

A critical review of scientific and technical literature shows that the disposal of wastes from various industries remains a challenge since their types and volumes are ever increasing [15]. This also applies to the disposal of waste from such industries as production of phosphate mineral fertilizers, alcohol and dairy products. One of the effective ways to dispose of these wastes is to recycle them for production of building materials [6-10], in particular, aerated concrete products. The purpose of these studies is to develop compositions and a production technology for modified non-autoclaved aerated concrete based on recycled industrial waste. The proposed technology is founded on an environmentally sustainable waste recycling mechanism. The mechanism is implemented

\footnotetext{
* Corresponding author: ev tkach@mail.ru
} 
through a two-step process: to prepare complex organic mineral modifiers and to produce non-autoclaved aerated concrete based on the developed modifiers that can reduce binder consumption by $20 \%$. Thus, it can be concluded that the search for new ways of recycling industrial waste in the production of environmentally friendly and high-performance aerated concrete should be continued.

\section{Materials and Methods}

Portland cement of class B32.5H produced at Kaluga Cement Plant LLC (Kaluga, Russia) was used as a binder for producing modified non-autoclaved aerated concrete based on recycled industrial waste. This cement was found to comply with the requirements of GOST 31108-2003. Common Cements. Specifications [11].

Quartz sands were used as a silica component. In terms of fine clay impurities, particlesize distribution and radiation hygiene assessment, these sands comply with the requirements of GOST 8736-93. Sand for Construction Works. Specifications [12].

Aluminum powder of PAP-2 grade was used as a blowing agent. It complies with the requirements of GOST 5494-95. Powder Aluminum. Specifications [13]. The fineness of the aluminum powder is $5,000 \mathrm{~cm}^{2} / \mathrm{g}$. The active aluminum content is $82 \%$. In terms of exposure to the human body, the dust of aluminum powder is assigned to hazard class III and belongs to the group of combustible substances as defined in GOST 12.1.005-88. General Hygiene Requirements for Working Zone Air [14]. It should be noted that aluminum is allowed to be used in paste form in aerated concrete production.

We analyzed the experience of using the common high-performance modifiers in aerated concrete production [15] and developed new compositions of complex organic mineral modifiers based on the industrial wastes listed below (Table 1).

Table 1. Compositions of complex organic mineral modifiers based on industrial waste.

\begin{tabular}{|c|c|c|c|c|}
\hline \multirow[b]{2}{*}{ Industrial waste } & \multicolumn{4}{|c|}{ Ingredients, $\mathrm{wt} \%$} \\
\hline & GM-SB* & GM-SBF* & $\begin{array}{l}\text { GM-SB* } \\
\text { plus STS }\end{array}$ & $\begin{array}{r}\text { GM-SBF* } \\
\text { plus STS }\end{array}$ \\
\hline Phosphogypsum & - & 40 & - & 25 \\
\hline Whey & 40 & 20 & 15 & 15 \\
\hline Distillers grains & 40 & 20 & 15 & 15 \\
\hline $\begin{array}{l}\text { Hardener - sodium } \\
\text { thiosulfate (STS) }\end{array}$ & - & & 45 & 20 \\
\hline Water & \multicolumn{4}{|c|}{ remaining } \\
\hline \multicolumn{5}{|c|}{$\begin{array}{l}\text { *GM-SB - oil-in-water emulsion; GM-SBF - emulsion and suspension (paste); } \\
\text { GM-SB plus STS and GM-SBF plus STS - dispersions with aqueous solutions of } \\
\text { inorganic acid salts. }\end{array}$} \\
\hline
\end{tabular}

In order to implement the industrial waste recycling process in aerated concrete production, we developed an environmentally sustainable mechanism that includes the following stages: environmental assessment of industrial waste and two-step recycling method. According to the environmental assessment, the test waste products are coded in the Federal Classificatory Catalog of Wastes (FCCW) and assigned to hazard class IV. (Table 2). 
Table 2. Environmental assessment of industrial wastes.

\begin{tabular}{|l|l|c|}
\hline FCCW code & \multicolumn{1}{|c|}{ Industrial waste } & Hazard class \\
\hline 31224111395 & Phosphogypsum & 4 \\
\hline 30121102395 & $\begin{array}{l}\text { Distillers grains from a federal state } \\
\text { unitary enterprise }\end{array}$ & 4 \\
\hline 30115000000 & Whey & 4 \\
\hline 94140152404 & Sodium thiosulfate & 4 \\
\hline
\end{tabular}

The effective specific activity $\left(A_{\text {eff }}\right)$ of natural radionuclides in the proposed phosphogypsum was found to be $110 \mathrm{~Bq} / \mathrm{kg}$. It is less than the limit value of $370 \mathrm{~Bq} / \mathrm{kg}$ required by GOST 30108-94. In terms of radioactivity, the material is assigned to class I. It is non-toxic, fire- and explosion-proof.

To combine the selected components, we developed methods for preparing the proposed organic mineral modifiers. These methods are conventionally called the first step of the environmentally sustainable mechanism. The technology behind the proposed methods is based on the following processes: preparation of oil-in-water emulsion GM-SB; preparation of emulsion and suspension (paste) GM-SBF; combination of dispersions with aqueous solutions of inorganic acid salts GM-SB plus STS and GM-CBF plus STS.

The second step of the environmentally sustainable mechanism is to produce nonautoclaved aerated concrete using the developed complex organic mineral modifiers. To accelerate curing of non-autoclaved aerated concrete, we used a heat-insulating hood. This technology was found to reduce energy consumption by $25 \%$ compared to conventional autoclave treatment, while allowing aerated concrete to reach the required strength within 5-6 hours. Activation with a rotary pulser adds up to $20 \%$ to the content of "ordinary" phosphogypsum in the modified aerated concrete in the presence of the organic mineral modifier GM-CBF plus STS. This treatment increases the recycled volume of the test waste products.

\section{Experiment}

Experimental studies were based on concrete samples of reference and test compositions (Table 3). The tests were carried out by a laboratory of the Department of Building Materials, National Research Moscow State University of Civil Engineering. The strength of aerated concrete was tested according to the methods specified in GOST 10180-2012. Concretes. Methods for Determining the Strength of Reference Samples [16], using a Controls MCC 8 laboratory-scale plant.

Table 3. Compositions of non-autoclaved aerated concretes (Grade D700).

\begin{tabular}{|c|c|c|c|c|c|c|c|}
\hline & \multirow{2}{*}{$\begin{array}{c}\text { Type of } \\
\text { composition }\end{array}$} & $\begin{array}{c}\text { W/S } \\
\text { ratio }\end{array}$ & \multicolumn{6}{|c|}{ Consumption of materials per $\mathrm{m}^{3}$ of aerated concrete, $\mathrm{kg}$} \\
\cline { 3 - 8 } & & Sand & $\begin{array}{c}\text { Aluminum } \\
\text { powder }\end{array}$ & $\begin{array}{c}\text { Caustic } \\
\text { soda }\end{array}$ & $\begin{array}{c}\text { Phosp } \\
\text { hogy } \\
\text { psum }\end{array}$ & $\begin{array}{c}\text { GM-SBF } \\
\text { plus STS }\end{array}$ \\
\hline $\begin{array}{c}\text { Reference } \\
\text { sample }\end{array}$ & 0.65 & 300 & 320 & 0.3 & 0.55 & - & - \\
\hline $\begin{array}{c}\text { Modified } \\
\text { sample }\end{array}$ & 0.55 & 240 & 300 & 0.3 & - & 55 & 5 \\
\hline
\end{tabular}


Using a FEI Quanta 200 SEM scanning electron microscope, a microstructural analysis of the test samples was performed. In order to measure the specific activity of natural radionuclides in phosphogypsum, a MKSP-01 Radek portable spectrometer was used directly on the disposal site. The thermal transmittance coefficient of the aerated concrete was determined with a MG4 250 thermal transmittance meter. This meter is designed to determine thermal transmittance and thermal resistance of materials at mean temperature of a sample from $+15^{\circ}$ to $+42.5^{\circ} \mathrm{C}$.

The validity of the results was confirmed by conventional and standard research methods, as well as by statistical processing of the obtained data that provided sufficient accuracy at a confidence level of at least $95 \%$.

\section{Results}

The analyzed effects of the organic mineral modifier on the properties of the concrete mixture and the concrete show that the proposed environmentally sustainable mechanism reduces the water-to-solid (W/S) ratio by $17 \%$ compared to the reference composition and increases the strength of the modified aerated concrete by $38 \%$ (Table 4 ). The increased strength of the test concrete can be explained by the fact that the matrix of interpore partitions is hardened by creating a modified structure. In terms of density, the proposed aerated concrete can be classified as a building thermal insulation material. The microstructural analysis of the modified aerated concrete samples (Fig. 1) confirms these findings.

Table 4. Properties of the modified aerated concrete.

\begin{tabular}{|c|c|c|c|c|}
\hline $\begin{array}{c}\text { Type of } \\
\text { concrete }\end{array}$ & $\begin{array}{c}\mathrm{W} / \mathrm{S} \\
\text { ratio }\end{array}$ & $\begin{array}{c}\text { Density } \\
\text { grade }\end{array}$ & $\begin{array}{c}\text { Ultimate tensile } \\
\text { strength, MPa }\end{array}$ & $\begin{array}{c}\text { Concrete strength } \\
\text { class }\end{array}$ \\
\hline $\begin{array}{c}\text { Reference } \\
\text { sample }\end{array}$ & 0.70 & $\mathrm{D} 700$ & 3.4 & $\mathrm{~B} 2.5$ \\
\hline $\begin{array}{c}\text { Modified } \\
\text { sample }\end{array}$ & 0.58 & $\mathrm{D} 700$ & 4.7 & $\mathrm{~B} 3.5$ \\
\hline
\end{tabular}

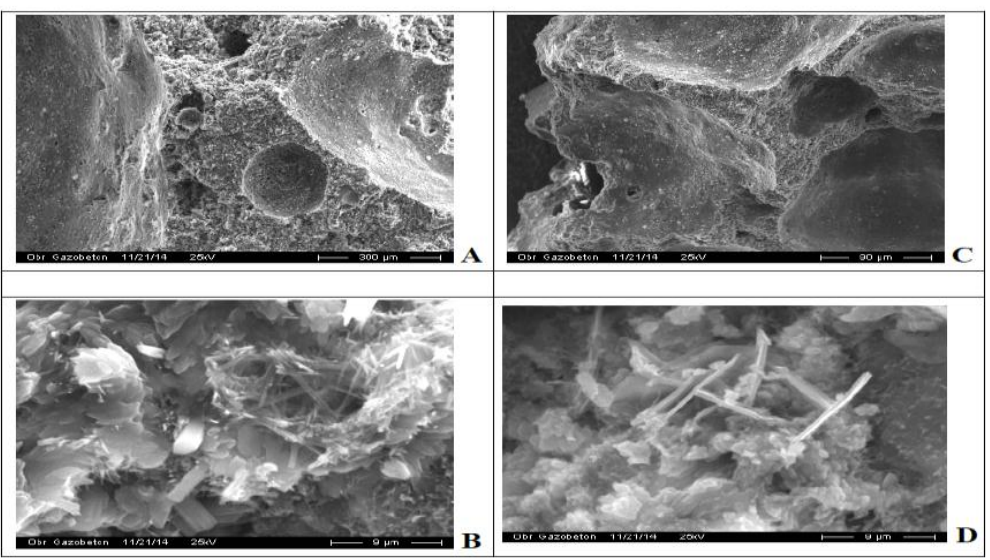

Fig. 1. Structure of the non-autoclaved aerated concrete: A, B - micro and macrostructure of the reference concrete sample; $\mathrm{C}, \mathrm{D}$ - micro- and macrostructure of the modified concrete sample.

The results presented in Table 5 demonstrate that the organic mineral modifier also has a certain effect on the generation of the fine aerated concrete structure with a pore diameter 
of no more than $800 \mu \mathrm{m}$, i.e. the "crushing" of the interpore space is almost twice as fine as that in the reference composition. The quality at which a new hydrophobic structure is generated significantly contributes to the reduction of gel and capillary porosity by $1.5 \ldots 2$ times. This is due to the improved physical and operational properties of the modified nonautoclaved aerated concrete.

The further studies demonstrate that the proposed modifiers have a clear positive effect on the frost resistance of the produced aerated concrete (Table 6).

According to the test results, the frost resistance grade of the modified aerated concrete is two steps higher than the conventional one: 75 versus 35 cycles. The softening coefficient of the modified aerated concrete was found to be $22 \%$ higher than the reference sample. The ice formed in the modified concrete acquires a porphyritic structure that changes the ice formation pattern, reduces the strength of adhesion with cement membranes and increases its fluidity in the interpore space. As a result, when it crystallizes, the pressure in concrete pores decreases considerably. The results provide evidence that the aerated concrete destruction process is inhibited by the hydrophobic effect [16-18], which significantly reduces the penetration of water into the aerated concrete.

Table 5. Porosity of the modified aerated concrete.

\begin{tabular}{|c|c|c|}
\hline Types of pores & Pore size, $\mathrm{cm}$ & Percentage of total porosity, $\%$ \\
\hline \multicolumn{3}{|c|}{ Reference sample } \\
\hline Gel & $1 \cdot 10^{-6}-5 \cdot 10^{-6}$ & $15-20$ \\
\hline Capillary & $8 \cdot 10^{-5}-2 \cdot 10^{-4}$ & $20-30$ \\
\hline Cellular & $10^{-4}-(0.12-0.15)$ & $60-75$ \\
\hline \multicolumn{3}{|c|}{ Modified aerated concrete } \\
\hline Gel & $1 \cdot 10^{-6}-5 \cdot 10^{-6}$ & $6-10$ \\
\hline Capillary & $8 \cdot 10^{-5}-2 \cdot 10^{-4}$ & $10-20$ \\
\hline Cellular & $10^{-4}-(0.05-0.08)$ & $75-85$ \\
\hline
\end{tabular}

Table 6. Frost resistance and water resistance of aerated concretes.

\begin{tabular}{|c|c|c|c|c|}
\hline \multirow{2}{*}{ Type of concrete } & \multicolumn{2}{|c|}{$\begin{array}{c}\text { Ultimate tensile } \\
\text { strength, MPa, }\end{array}$} & \multirow{2}{*}{$\begin{array}{c}\text { Softening } \\
\text { coefficient }\end{array}$} & $\begin{array}{c}\text { Frost resistance } \\
\text { grade }\end{array}$ \\
\cline { 2 - 3 } & dry & $\begin{array}{c}\text { water } \\
\text { saturated }\end{array}$ & \\
\hline Reference sample & 3.0 & 2.1 & 0.7 & F35 \\
\hline Modified & 4.7 & 4.0 & 0.85 & F75 \\
\hline
\end{tabular}

The organic mineral modifiers added to the composition improve the thermal transmittance of aerated concrete by improving the quality of its porosity and reducing the moisture transfer process. The graph presented in Figure 2 shows that the thermal transmittance coefficient of the modified aerated concrete is $0.143 \mathrm{~W} /\left(\mathrm{m} \cdot{ }^{\circ} \mathrm{C}\right)$, which is $23 \%$ less than that of the conventional aerated concrete $\left(0.177 \mathrm{~W} / \mathrm{m} \cdot{ }^{\circ} \mathrm{C}\right)$ at equal mean density $\left(700 \mathrm{~kg} / \mathrm{m}^{3}\right)$. 


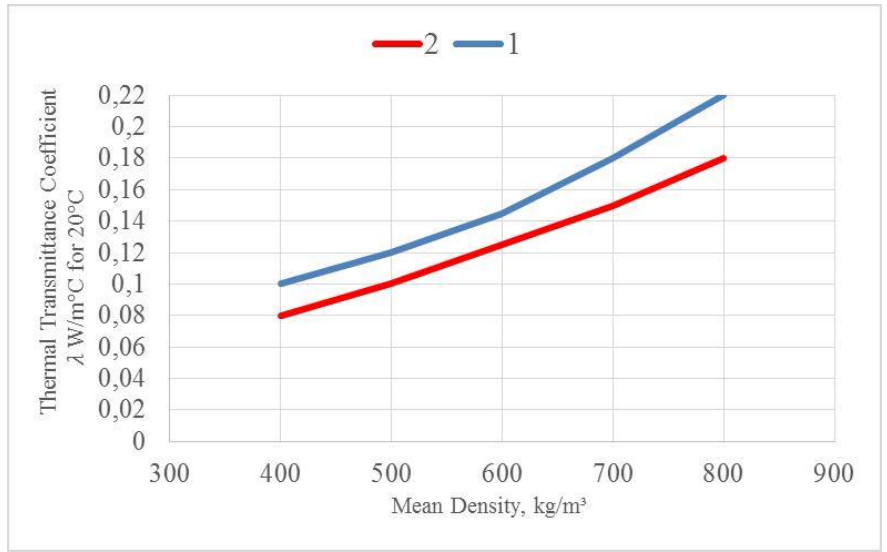

Fig. 2. Thermal transmittance coefficient: 1 - conventional aerated concrete; 2 - modified aerated concrete.

Thus, based on the experimental studies, it can be generally concluded that the proposed environmentally sustainable mechanism is appropriate not only for recycling industrial wastes from a variety of industries, but also for producing high-performance aerated concrete products with improved physical and operational properties. The produced concretes have improved quality indicators, including strength (by 38\%), frost resistance (by two steps, up to F75) and softening coefficient (by 22\%). This is accompanied with $23 \%$ decrease in the thermal transmittance coefficient, which reduces heat transfer through walls during the heating season as compared to the conventional aerated concrete and mitigates the greenhouse effect.

\section{Conclusion}

The results of the studies show that their purpose was achieved. The compositions and the production technology for modified non-autoclaved aerated concrete based on recycled industrial waste and ensuring the required level of environmental safety were developed. The application field of the results does not conflict with the applicable laws that regulate the environmental assessment for planned industrial or civil construction areas, and recycling of industrial waste in the production of aerated concrete with improved construction and operational properties.

\section{References}

1. V.I. Telichenko, D.V. Oreshkin, Ecology of urban areas 2, 31-33 (2015) (in Russian)

2. M.V. Grafkina, A.D. Potapov, Vestnik MGSU 1, 23-28 (2008) (in Russian)

3. V.I. Telichenko, M.Ju. Slesarev, Ecology of urban areas 4, 6-9 (2014) (in Russian)

4. A.D. Potapov, E.V.Shubina, P.M. Zhuk, Vestnik MGSU 4, 128-134 (2010) (in Russian)

5. L.A Suleymanova, V.S Lesovik, K.A. Kara, M.V. Malyukova, K.A. Suleymanov, Research Journal of Applied Sciences 9 (12), 1087-1090 (2014)

6. D.V. Oreshkin, A.N. Chebotaev, V.A. Perfilov, Procedia Engineering 111, 607-611 (2015)

7. R. Duval, E.H. Kadri, Cement and Concrete 4, 533-547 (1998)

8. C. Shi, J. Qian, Resource Conserve Recycle 29, 195-207 (2000) 
9. A. Grishina, E. Korolev, Proceedings of the XIII International Conference of Students and Young Scientists, 020003 (2015)

10. A. Grishina, E. Korolev, Proceedings of the XIII International Conference of Students and Young Scientists, 020016 (2016)

11. GOST 31108-2016. Common cements. Specifications (2016)

12. GOST 8736-2014. Sand for construction works. Specifications (2015)

13. GOST 5494-95. Powder aluminum. Specifications (1997)

14. GOST 12.1.005-88. General hygiene requirements for working zone air (1989)

15. E.V. Tkach, V.C. Semenov, S.A. Tkach, T.A. Rozovskaya, Procedia $24^{\text {th }}$ Cep. XXIV R-S-P seminar - Theoretical Foundation of Civil Engineering (TFoCE), 763-769 (2015)

16. GOST 10180-2012. The concretes. Methods for determining the strength of reference samples (2013)

17. A.D. Zhukov, A.V. Chugunkov, A.O. Himich, A.A. Eremenko, N.A. Kopylov, Vestnik MGSU 7, 167-175 (2013) (in Russian)

18. Yu.M. Bazhenov, E.M. Chernyshov, D.N. Korotkih, Stroitel'nye Materialy [Building materials] 3, 6-14 (2014) (in Russian) 